\title{
Occurrence of pressure injury in patients hospitalized in a school hospital
}

\author{
Ocorrência de lesão por pressão em pacientes internados em um hospital-escola
}

Aparición de lesión por presión en pacientes internados en un hospital-escuela

Juliana Magali Barbosaํ, Geraldo Magela Salomé1

ORCID IDs

Barbosa JM (iD https://orcid.org/0000-0003-0583-8438

Salomé GM (D) https://orcid.org/0000-0002-7315-4866
HOW TO CITE

Barbosa JM; Salomé GM. Occurrence of pressure injury in patients hospitalized in a school hospital. ESTIMA, Braz. J. Enterostomal Ther., 16: e2718. https://doi.org/10.30886/estima.v16.523

The author Barboa JM acknowledges the scholarship of Programa de Bolsa de Iniciação Científica (PROBIC) of Fundação de Amparo à Pesquisa do Estado de Minas Gerais (FAPEMIG).

\begin{abstract}
Objective: to evaluate the occurrence and risk factors for the development of pressure injury (PI) in patients admitted in medical and surgical clinics and in observation at the emergency room of a university hospital. Methods: Cross-sectional, descriptive-exploratory, epidemiological study. Patients were assessed by physical examination three times a week for two consecutive months between June and November 2016. Results: the frequency of PI was 29\% $(n=9)$ in the medical clinic, $16 \%(n=4)$ in the surgical clinic and 53.8\% $(n=7)$ in observation at the emergency room. According to the Braden scale, seven (30.4\%) patients in the medical clinic presented high risk and two (25\%) moderate risk; three (27.3\%) patients from the surgical clinic presented a high risk and one (7.1\%) moderate risk; and seven (58.3\%) patients in observation at the emergency room were high risk. The risk factors associated with the participants who developed PI were: restriction in the bed, use of catheters or devices, vasoactive drug, diaper, mechanical ventilation, sedatives, unconsciousness, food fasting and hospitalization time over 10 days. Conclusion: there was a high frequency of PI in the medical and surgical clinics and in observation at the emergency room. Most patients were high risk for developing PI.
\end{abstract}

DESCRIPTORS: Pressure injury; Risk measurement; Nursing care; Stomatherapy.

\footnotetext{
1 Universidade do Vale do Sapucaí, Faculdade de Ciências Médicas Dr. José Antônio Garcia Coutinho, Escola de Enfermagem - Pouso Alegre/MG - Brazil.

Corresponding author: Geraldo Magela Salomé | Universidade do Vale do Sapucaí - Campus Fátima | Av. Prefeito Tuany Toledo, 470 | ZIP Code: 37550-000 - Pouso Alegre/MG - Brazil | E-mail: salomereiki@univas.edu.br

Received: Aug 282017 | Accepted: Oct 172017
} 


\section{RESUMO}

Objetivo: Avaliar a ocorrência e fatores de risco para o desenvolvimento de lesão por pressão (LP) em pacientes internados nas clínicas médica, cirúrgica e de observação do pronto-socorro de um hospital universitário. Métodos: Estudo transversal, descritivoexploratório, de caráter epidemiológico. Os pacientes foram avaliados por meio de exame físico, três vezes por semana, durante dois meses consecutivos, entre junho e novembro de 2016. Resultados: A frequência de LP foi de 29\% ( $n=9)$ na clínica médica, 16\% ( $n=$ 4) na clínica cirúrgica e 53,8\% ( $n=7)$ na observação do pronto-socorro. Segundo a escala de Braden, sete (30,4\%) pacientes da clínica médica apresentaram risco elevado e dois (25\%) risco moderado; três (27,3\%) pacientes da clínica cirúrgica apresentaram risco elevado e um $(7,1 \%)$ risco moderado; e sete $(58,3 \%)$ pacientes na observação do pronto-socorro apresentaram risco elevado. Os fatores de risco associados aos participantes que desenvolveram LP foram: restrição no leito, o uso de cateteres ou dispositivos, droga vasoativa, fralda, ventilação mecânica, sedativos, inconsciência, jejum alimentar e tempo de internação acima de 10 dias. Conclusão: Houve alta frequência de LP nas clínicas médica e cirúrgica e na observação do pronto-socorro. A maioria dos pacientes apresentou risco elevado para desenvolver LP.

\section{DESCRITORES: Lesão por pressão; Medição de risco; Cuidados de enfermagem; Estomaterapia.}

\section{RESUMEN}

Objetivo: Evaluar la incidencia y factores de riesgo para el desarrollo de lesión por presión (LP) en pacientes internados en las clínicas médica, quirúrgica y de observación de la sala de urgencia, de un hospital universitario. Métodos: Estudio transversal, descriptivoexploratorio, de carácter epidemiológico. Los pacientes fueron evaluados por medio de examen físico, tres veces por semana, durante dos meses consecutivos, entre junio y noviembre de 2016. Resultados: La frecuencia de LP fue de 29 \% ( $n=9$ ) en la clínica médica, 16\% $(n=4)$ en la clínica quirúrgica y 53,8 \% ( $n=7)$ en la observación de la sala de urgencia. Según la escala de Braden, siete (30,4\%) pacientes de la clínica médica presentaron riesgo elevado y dos (25\%) riesgo moderado; tres (27,3\%) pacientes de la clínica quirúrgica presentaron riesgo elevado y uno $(7,1 \%)$ riesgo moderado; y siete $(58,3 \%)$ pacientes en la observación de la sala de urgencia presentaron riesgo elevado. Los factores de riesgo asociados a los participantes que desarrollaron LP fueron: restricción en la cama, el uso de catéteres o dispositivos, droga vasoactiva, pañal, ventilación mecánica, sedantes, inconsciencia, ayuno alimenticio y tiempo de internación por encima de 10 días. Conclusión: Hubo alta frecuencia de LP en las clínicas médica y quirúrgica y en la observación de la sala de urgencia. La mayoría de los pacientes presentó riesgo elevado para desarrollar LP.

DESCRIPTORES: Lesión por presión; Medición de riesgo; Cuidados de enfermería; Estomaterapia.

\section{INTRODUCTION}

Pressure injuries (PI) are localized injuries on a bone prominence and in soft parts, being superficial or deep, of ischemic etiology, secondary to an increase of external pressure $^{1,2}$. National and international studies have incidence rates of PI ranging from 1 to $35 \%$ in hospitalized patients ${ }^{3-7}$. The prevalence of PI in a general hospital is quite variable in the national and international literature, ranging from 7 to $29 \%$ and from 15 to $25 \%$ in patients with chronic diseases ${ }^{4,8,9}$.

Some hospitalized patients are at high risk for developing PI due to neurological impairment and mobility limitations. Many are receiving sedative and analgesic drugs, which decrease sensory perception and impair mobility; others are undernourished or obese. Other factors, both intrinsic and extrinsic, including age, vasoactive drug use, nutritional status, anemia, infections, cutaneous sensitivity, incontinence, hemodynamic instability, agitation, moisture, friction and shear also contribute to the development of PI. Patients with these characteristics represent a priority group for the health professional, since they present risk factors for PI development. With this in mind, the health professional should use a risk factor assessment scale. When identifying the risk factors, the professional should adopt measures that reduce pressure, friction and shear on the skin on bony prominences, such as the use of suitable mattresses, cushion, changes of decubitus, coverings with hydrocolloid plate, transparent polyurethane film, among others ${ }^{3,10-12}$.

In order for the professional to be able to develop programs of preventive measures to reduce the occurrence of PI, it is necessary for it to have epidemiological knowledge about its prevalence and incidence, the factors that contribute most to its development and those that control its presence or absence. Epidemiological indicators are very useful because its measure the temporal evolution of a problem. Prevalence and incidence are the most used indicators in PI studies. Increasingly, nurses, health professionals and managers have the responsibility to ensure the quality of care provided to patients and to adjust this care according to the results obtained ${ }^{13-15}$. 


\section{OBJECTIVE}

To evaluate the occurrence and risk factors for the development of PI in patients in the medical clinic, surgical and observation unit of the emergency room of a university hospital in the southern state of Minas Gerais (MG).

\section{METHODS}

This is a cross-sectional epidemiological study.

The research project was approved by the Ethics and Research Committee by the Faculty of Medical Sciences Dr. José Antônio Garcia Coutinho of the University of Vale do Sapucaí (UNIVAS), under the opinion Certificate of Presentation for Ethical Assessment (CAAE) 01883312.6.0000.5102. All participants or companions signed the Free and Informed Consent Form.

The target population consisted of 69 patients, both genders, hospitalized without PI at the Samuel Libanio Clinics Hospital of UNIVAS, located in Pouso Alegre, $\mathrm{MG}$, and who were hospitalized in the medical clinic, clinic surgery and observation of the emergency room sectors for a period of 48 hours or more.

Patients aged 18 years or less and patients who remained in the hospital for less than 48 hours were not included in the study. Patients who, during the collection of data, refused to be evaluated were excluded, that is, it did not allow the researcher to inspect the skin during the study.

Data collection was performed on Mondays, Wednesdays and Fridays, during two consecutive months, in each sector. Data collection was initiated in June 2016 and ended in November 2016. The instruments used to collect data were: a questionnaire for recording socio-demographic data (age, gender, color, length of stay), clinical data (diabetes mellitus, hypertension, smoking), data related to risk factors (body mass index, bed restriction, use of catheters and devices, use of diaper, urinary incontinence, mechanical ventilation, use of sedation, use of drug, motor turmoil, food fasting) and Braden scale.

It chose to use the Braden scale for having been translated and validated into the Portuguese language. This scale is composed of six subscales that measure the degree of sensory perception, humidity, physical activity, nutrition, mobility, friction and shear. All subscales are graded from 1 to 4 , except friction and shear, whose variation is from 1 to 3 . The variation of the scale score is from 6 to 23 points, being: very high risk, from 6 to 9 points; high risk, from 10 to 12 points; moderate risk, from 13 to 14 points, low risk, from 15 to 18 points; and risk free, more tha 19 points. In this present study was considered high risk patients those who showed high risk or very high risk of developing PI, which means, scoring between 6 to 12 points.

For statistical analysis, Fisher's exact test and the chi-square test were used. The value of $\mathrm{p}<0.05$ was considered a level of statistical significance for the tests.

\section{RESULTS}

The data presented in Table 1 show that the frequency of PI was $29 \%(n=9)$ in the medical clinic, $16 \%(n=4)$ in the surgical clinic and $53.8 \%(n=7)$ in the observation of Emergency Room.

Table 1. Occurrences of pressure injuries (PI) during hospitalization in a school hospital. Pouso Alegre, Minas Gerais, Brazil, 2016.

\begin{tabular}{cccc} 
PI & \multicolumn{3}{c}{ Sector } \\
\cline { 2 - 4 } & $\begin{array}{c}\text { Medical clinic } \\
\mathbf{n}(\%)\end{array}$ & $\begin{array}{c}\text { Surgical clinic } \\
\mathbf{n}(\%)\end{array}$ & $\begin{array}{c}\text { Observation } \\
\mathbf{n}(\%)\end{array}$ \\
\hline Yes & $9(29.0)$ & $4(16.0)$ & $7(53.8)$ \\
\hline No & $22(71.0)$ & $21(84.0)$ & $6(46.2)$ \\
\hline Total & $31(100.0)$ & $25(100.0)$ & $13(100.0)$ \\
\hline
\end{tabular}

In Table 2, it was observed that the majority of study participants who developed PI were between 60 and 96 years of age, women and white, and there was no statistical difference between the variables.

In Table 3, it can verify the occurrence of PI related to clinical data in patients who participated in the study. Among the patients hospitalized in the medical clinic, six (35.3\%) were underweight and two (28.6\%) were overweight. Among the patients admitted to the surgical clinic, three (25\%) had normal weight and one (20\%) had obesity. Among the hospitalized patients in observation, four (80\%) were underweight. Most of the patients who participated in the study were diabetic and had no hypertension. There was no statistical difference between the variables.

Table 4 shows that all patients who participated in the study and who developed PI had a moderate to high risk for the development of this condition, according to the Braden scale scores. There was no statistical difference between the variables. 
Table 5 shows the risk factors of patients who participated in the research and who developed PI; all were restricted to the bed, its used catheters or devices and vasoactive drugs, its used diapers, its were on mechanical ventilation, sedated, in unconsciousness and food fasting and with a period of hospitalization over 10 days.

Table 2. Occurrences of pressure injuries (PI) during hospitalization in a school hospital, according to sociodemographic variables. Pouso Alegre, Minas Gerais, Brazil, 2016.

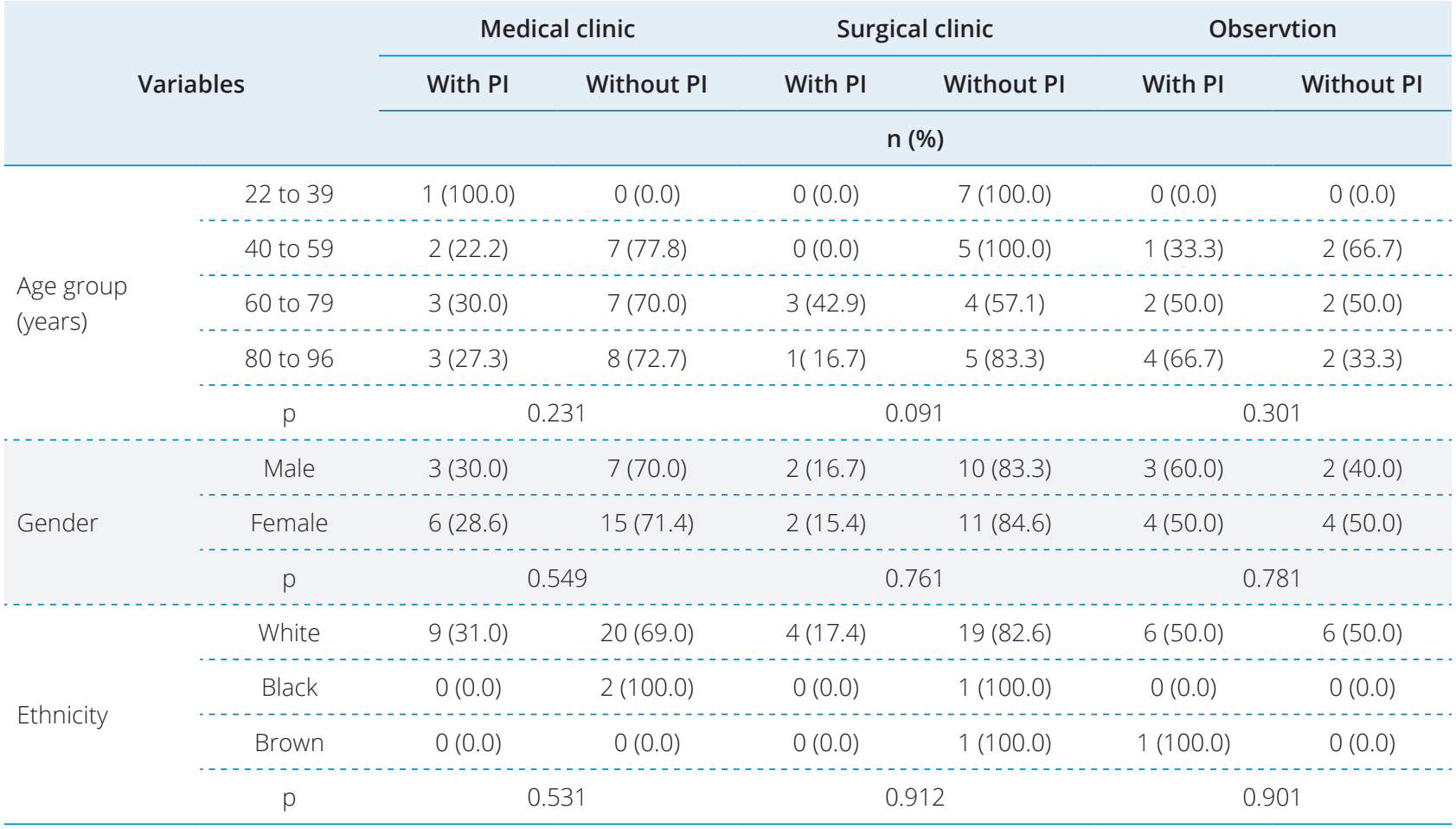

Statistical significance level $(p<0,05)$.

Table 3. Occurrences of pressure injuries (PI) during hospitalization in a school hospital, according to clinical variables. Pouso Alegre, Minas Gerais, Brazil, 2016.

\begin{tabular}{|c|c|c|c|c|c|c|c|}
\hline \multirow{3}{*}{\multicolumn{2}{|c|}{ Variables }} & \multicolumn{2}{|c|}{ Medical clinic } & \multicolumn{2}{|c|}{ Surgical clinic } & \multicolumn{2}{|c|}{ Observtion } \\
\hline & & With PI & Without PI & With PI & Without PI & With PI & Without PI \\
\hline & & \multicolumn{6}{|c|}{ n (\%) } \\
\hline \multirow{5}{*}{$\begin{array}{l}\text { Body mass } \\
\text { index }\end{array}$} & Underweight & $6(35.3)$ & $11(64.7)$ & $0(0.0)$ & $3(100.0)$ & $4(80.0)$ & $1(20.0)$ \\
\hline & Normal & $0(0.0)$ & $2(100.0)$ & $3(25.0)$ & $9(75.0)$ & $1(50.0)$ & $1(50.0)$ \\
\hline & Overweight & $2(28.6)$ & $5(71.4)$ & $0(0.0)$ & $5(100.0)$ & $1(20.0)$ & $4(80.0)$ \\
\hline & Obesity & $1(20.0)$ & $4(80.0)$ & $1(20.0)$ & $4(80.0)$ & $1(100.0)$ & $0(0.0)$ \\
\hline & $p$ & \multicolumn{2}{|c|}{0.701} & \multicolumn{2}{|c|}{0.502} & \multicolumn{2}{|c|}{0.2017} \\
\hline \multirow{3}{*}{$\begin{array}{l}\text { Diabetes } \\
\text { mellitus }\end{array}$} & Yes & $4(33.3)$ & $8(66.7)$ & $0(0.0)$ & $5(100.0)$ & $4(57.1)$ & $3(42.9)$ \\
\hline & No & $5(26.3)$ & $14(73.7)$ & $4(20.0)$ & $16(80.0)$ & $3(50.0)$ & $3(50.0)$ \\
\hline & $\mathrm{p}$ & \multicolumn{2}{|c|}{0.695} & \multicolumn{2}{|c|}{0.441} & \multicolumn{2}{|c|}{0.761} \\
\hline \multirow{3}{*}{$\begin{array}{l}\text { Systemic } \\
\text { arterial } \\
\text { hypertension }\end{array}$} & Yes & $4(26.7)$ & $11(73.3)$ & $1(14.3)$ & $6(85.7)$ & $5(55.6)$ & $4(44.4)$ \\
\hline & No & $5(31.3)$ & $11(68.8)$ & $3(16.7)$ & $15(83.3)$ & $2(50.0)$ & $2(50.0)$ \\
\hline & $p$ & \multicolumn{2}{|c|}{0.871} & \multicolumn{2}{|c|}{0.781} & \multicolumn{2}{|c|}{0.843} \\
\hline
\end{tabular}

Statistical significance level $(p<0,05)$. 
Table 4. Occurrences of pressure injuries (PI) during hospitalization in a school hospital, according to the Braden scale. Pouso Alegre, Minas Gerais, Brazil, 2016.

\begin{tabular}{|c|c|c|c|c|}
\hline \multirow{3}{*}{ Sector } & \multirow{3}{*}{ PI } & \multicolumn{3}{|c|}{ Braden Scale } \\
\hline & & Moderate & High & $p$ \\
\hline & & \multicolumn{3}{|c|}{$\mathrm{n}(\%)$} \\
\hline \multirow{3}{*}{ Medical clinic } & Yes & $2(25.0)$ & $7(30.4)$ & \multirow{3}{*}{0.321} \\
\hline & No & $6(75.0)$ & 16 (69.6) & \\
\hline & Total & $8(100.0)$ & $23(100.0)$ & \\
\hline \multirow{3}{*}{ Surgical clinic } & Yes & $1(7.1)$ & $3(27.3)$ & \multirow{3}{*}{0.231} \\
\hline & No & $13(92.9)$ & $8(72.7)$ & \\
\hline & Total & $14(100.0)$ & $11(100.0)$ & \\
\hline \multirow{3}{*}{ Observation } & Yes & $0(0.0)$ & $7(58.3)$ & \multirow{3}{*}{0.431} \\
\hline & No & $1(100.0)$ & $5(41.7)$ & \\
\hline & Total & $1(100.0)$ & $12(100.0)$ & \\
\hline
\end{tabular}

Fisher exact test. Statistical significance level $(p<0.05)$.

Table 5. Occurrences of pressure injuries (PI) during hospitalization at a school hospital, according to the risk factors for PI. Pouso Alegre, Minas Gerais, Brazil, 2016.

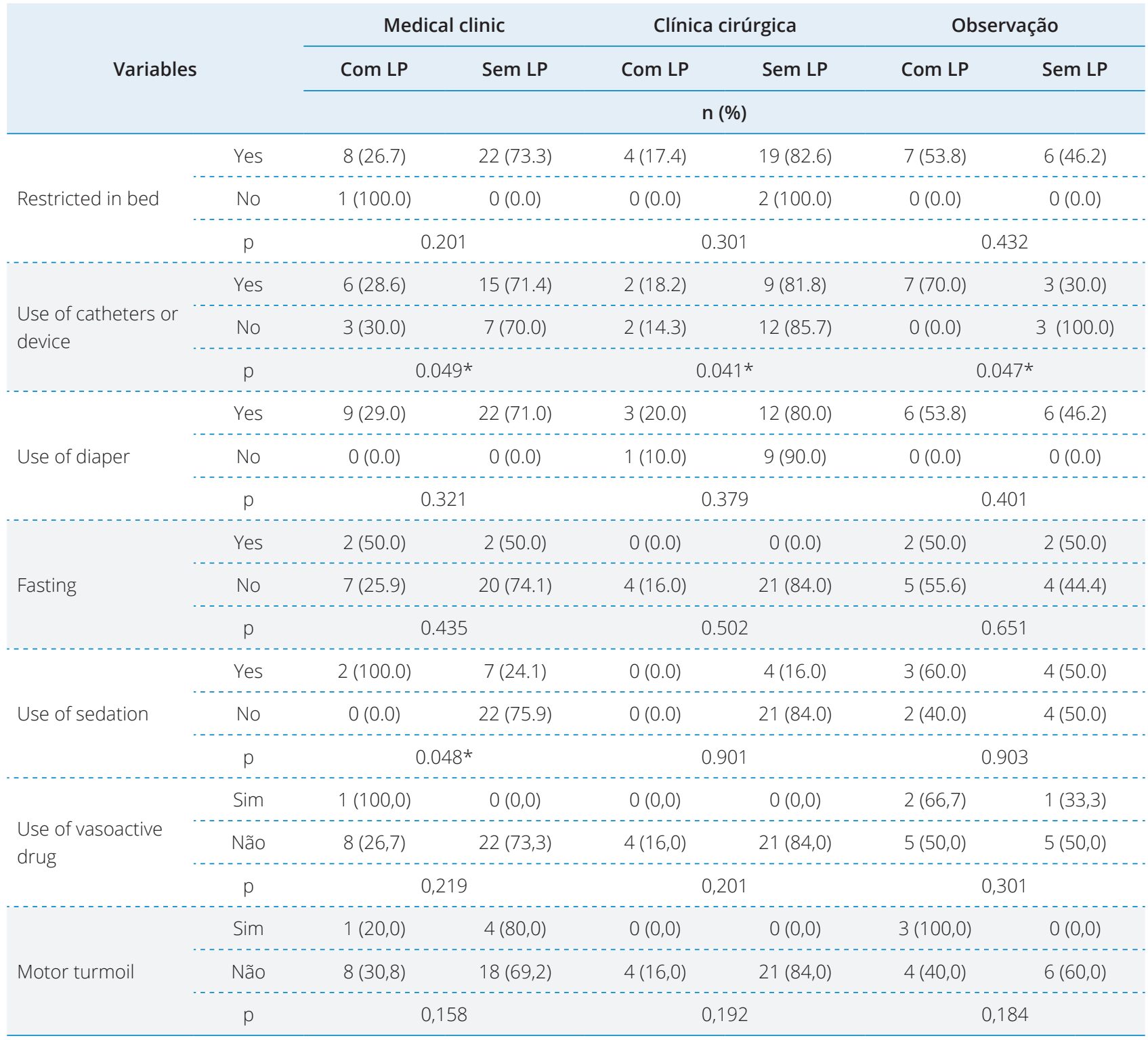


Table 5. Continuation...

\begin{tabular}{|c|c|c|c|c|c|c|c|}
\hline & Yes & $3(75.0)$ & $1(25.0)$ & $1(50.0)$ & $1(50.0)$ & $3(60.0)$ & $2(40.0)$ \\
\hline \multirow[t]{3}{*}{ Unconsicous } & No & $6(22.2)$ & $21(77.8)$ & $3(13.0)$ & $20(87.0)$ & $4(50.0)$ & $4(50.0)$ \\
\hline & $p$ & \multicolumn{2}{|c|}{0.049} & \multicolumn{2}{|c|}{0.291} & \multicolumn{2}{|c|}{0.911} \\
\hline & $\begin{array}{l}\text { Less than } \\
10\end{array}$ & $2(13.3)$ & $13(86.7)$ & $1(6.3)$ & $15(93.8)$ & $6(54.5)$ & $5(45.5)$ \\
\hline \multirow{4}{*}{$\begin{array}{l}\text { Period of } \\
\text { hospitalization } \\
\text { (days) }\end{array}$} & $\begin{array}{l}10 \text { or } \\
\text { more }\end{array}$ & 7 (43.8) & $9(56.3)$ & 3 (33.3) & $6(66.7)$ & $1(50.0)$ & $1(50.0)$ \\
\hline & Total & $9(29.0)$ & $22(71.0)$ & 4 (16.0) & $21(84.0)$ & 7 (53.8) & $6(46.2)$ \\
\hline & p & \multicolumn{2}{|c|}{$0.031 *$} & \multicolumn{2}{|c|}{$0.039 *$} & \multicolumn{2}{|c|}{0.028} \\
\hline & Yes & $3(100.0)$ & $0(0.0)$ & $0(0.0)$ & $0(0.0)$ & $3(50.0)$ & $3(50.0)$ \\
\hline \multirow{2}{*}{$\begin{array}{l}\text { Use of mechanical } \\
\text { ventilation }\end{array}$} & No & $6(21.4)$ & $22(78.6)$ & 4 (16.0) & $21(84.0)$ & $4(57.1)$ & $3(42.9)$ \\
\hline & $p$ & \multicolumn{2}{|c|}{$0.019 *$} & \multicolumn{2}{|c|}{0.901} & \multicolumn{2}{|c|}{0.991} \\
\hline
\end{tabular}

Fisher exact test. *Statistical significance $(p<0.05)$.

\section{DISCUSSION}

The result of this study points to a frequency of PI occurrence of $29 \%$ in the medical clinic, $16 \%$ in the surgical clinic and $53.8 \%$ in the emergency room observation. The results show a high frequency when compared to other studies ${ }^{18-20}$. In a similar study, the authors identified PI frequency of $22 \%$ in critical patients ${ }^{17}$. In another study, the frequency was $20.6 \%$ in surgical clinic sectors ${ }^{18}$.

To identify PI, all patients in the study were submitted a physical examination of the skin and the Braden scale, and most of the patients presented a high risk for PI development. Several studies corroborate the results obtained $^{11,16,19}$.

The results of a study with the objective of analyzing the risk factors for the development of PI in adult patients admitted to intensive care centers, which included 140 patients, showed, using the Braden scale, that patients hospitalized for 15 days or more presented some category of risk. The most frequent PI occurrences were found in patients who were in the categories: sensory perception (completely limited), humidity (constantly moist), mobility (completely immobilized), activity (bedridden), nutrition (adequate) and friction and shear (problem). The authors concluded that the use of the Braden scale is an important strategy in the care of intensive care patients ${ }^{21}$.
In this study, most of the patients had the following risk factors: age over 61 years, being restricted in the bed, use of catheters or devices, vasoactive drug, use of diaper, mechanical ventilation, sedation, unconsciousness, fasting, with a period of hospitalization longer than 10 days and being underweight or overweight.

The decrease in the level of consciousness due to diseases of neurological origin or sensory perception causes the brain to have difficulty identifying what is occurring with the patient through nerve stimuli, reducing its perception of discomfort and/or pain, reducing, thus, the patient's mobility and activity, which may lead to the development of PI. Among the neurological and mobility modifications, coma, immobilization and paresthesias ${ }^{6}$.

In a study that evaluated the incidence of PI, the authors concluded that one of the factors that leads the patient to develop PI is its limitation, since $90 \%$ of the patients who developed this condition were completely limited, while in the mobility, $95 \%$ of subjects were immobile $^{19}$.

In another study, the authors concluded that 95\% of patients with inadequate nutrition had difficulty maintaining tissue integrity of the skin, in addition to regeneration problems and in the scar process of the $\operatorname{skin}^{23}$.

The group of prophylactic actions begins in the identification of the susceptible patient. The physical examination and the clinical history are, in most cases, sufficient for the estimation of the risk, which will determine 
the interventions to be performed. The estimation of the individual risk should be performed periodically and the use of risk measurement scales may be useful in preventive management ${ }^{24}$. Thus, it is emphasized that prophylactic measures regarding PI are of fundamental importance, especially for critical patients. For the prevention of PI to be effective, adequate training of health professionals is necessary, together with the financial support of the institutions to provide adequate training and materials. Also with regard to the financial aspects, the use of pressure redistributing devices that present a high cost for the institutions is mentioned; however, the effectiveness of these products makes this investment can reduce the length of stay and reflect positively on the quality of health services provided ${ }^{13-15}$.

\section{CONCLUSION}

The results of this study show that the frequency of occurrence of PI in the medical clinic was 29\%, in the surgical clinic $16 \%$ and in the emergency room observation 53.8\%. PI were predominantly developed in women patients, white and in the age group between 60 and 96 years. The risk factors or predictors of PI development found in the study were: hospitalization period of 10 days or more, patients restricted in the bed, use of catheters or devices, use of vasoactive drugs, diapers, mechanical ventilation, sedated patients, incontinence urinary and food fasting. Regarding body mass index, the majority of the patients were underweight or overweight. The majority of patients presented a high risk for PI development, according to the results of the Braden scale.

\section{AUTHORS'S CONTRIBUTION}

Conceptualization, Salome GM; Methodology, Salome GM; Investigation, Barbosa JM and Salome GM; Writing - First version, Barbosa JM and Salome GM; Writing - Review \& Editing, Salome GM; Resources, Salome GM; Supervision, Salome GM.

\section{REFERENCES}

1. Edsberg LE, Black JM, Goldberg M, McNichol $L$, Moore L, Sieggreen M. Revised national pressure ulcer advisory panel pressure injury staging system: revised pressure injury staging system. J Wound Ostomy Continence Nurs. 2016;43(6):585-97.

WON.000000000000028

2. Sieggree N. National pressure ulcer advisory panel responds to editorial. Adv Skin Wound Care. 2016; 29(12):535. https://doi. org/10.1097/01.ASW.0000508227.61503.f9

3. Dutra RA, Salomé GM, Alves JR, Perreira VO, Miranda FD, Valim FD, et al. Using transparent polyurethane film and hydrocolloid dressings to prevent pressure ulcers. I Wound Care. 2015; 24(6):268-75.https://doi. org/10.12968/jowc.2015.24.6.268

4. Lourenco L, Blanes L, Salomé GM, Ferreira LM Quality of life and self-esteem in patients with paraplegia and pressure ulcers: a controlled crosssectional study. J Wound Care. 2014;23(6):331-7. https://doi.org/10.12968/jowc.2014.23.6.331

5. Dutra RA, Salomé GM, Leal LM, Alves MG, Moura JP, Silva AT, et al. Cost comparison of pressure ulcer preventive dressings: hydrocolloid dressing versus transparent polyurethane film. I Wound Care.
2016;25(11):635-40. $\quad$ https://doi.org/10.12968/ jowc.2016.25.11.635

6. Rogenski NM, Kurcgant P. Avaliação da concordância na aplicação da escala de Braden interobservadores. Acta Paul Enferm. 2012;25(1):24-8.

7. Schlüer $A B$. Pressure ulcers in maturing skin - A clinical perspective. J Tissue Viability. 2017;26(1):25.https://doi.org/10.1016/j.jtv.2016.10.001

8. de Lima EL, de Brito MJ, de Souza DM, Salomé GM, Ferreira LM. Cross-cultural adaptation and validation of the neonatal/infant Braden Q risk assessment scale. J Tissue Viability. 2016;25(1):5765. https://doi.org/10.1016/j.jtv.2015.12.004

9. de Araújo TM, de Araújo MF, Caetano JÁ. Using the Braden scale and photographs to assess pressure ulcer risk. Rev ESC Enferm USP. 2012:46(4):858-64.

10. Marques ADB, Branco JGO, Cavalcante RC, Brito MCC, Deus SRM, Luz MHBA. Conhecimento dos profissionais de saúde da família sobreúlcera por pressão. Rev Estima. 2017;15(2):63-73. https:// doi.org/10.5327/Z1806-3144201700020002

11. Queiroz AC, Mota DD, Bachion MM, Ferreira AC. Pressure ulcers in palliative home care patients: prevalence and characteristics. Rev Esc Enferm USP. 2014;48(2):264-71. https://doi. 
org/10.1590/S0080/6234201400002000010

12. Santos LRO, Avelino FVSD, Luz MHB, Cavalcante TB, Silva JLM, Santos CAPS. Demographic and clinical characteristics of intensive therapy units patients with pressure ulcer. I Nurs UFPE Online. 2016;10(Suppl. 1):225-31. https://doi.org/10.5205/reuol.7901-80479-1SP.1001sup201605

13. Vieira DS, Comassetto I, Faro ACM, Monteiro VGN, AlmeidaTG, Alves KMC. Interdisciplinary care to patients with pressure J Nurs UFPE Online. 2016;10(7):2428-35. https://doi.org/10.5205/ reuol.9106-80230-1-SM1007201617

14. Van Leen MW, Schols JM, Hovius SE, Halfens RJ. The effect of a simple 3-step pressure relieving strategy for preventing pressure ulcers: an explorative longitudinal study from 2002-2011. Wounds. 2014;26(10):285-92.

15. Van Leen M, Hovius S, Halfens R, Neyens J, Schols J. Pressure relief with visco-elastic foam or with combined static air overlay? A prospective, crossover randomized clinical trial in a Dutch nursing home. Wounds. 2013;25(10):287-92.

16. Paranhos WY, Santos VLCG. Avaliação do risco para úlceras de pressão por meio da escala de Braden na língua portuguesa. Rev Esc Enferm USP. 1999;33(Espec):191-204.

17. Borghardt AT, Prado TN, Bicudo SDS, Castro DS, Bringuente ME. Úlcera por pressão em pacientes críticos: incidência e fatores associados. Rev Bras Enferm. 2016;69(3):460-7. https://doi. org/10.1590/0034-7167.2016690307i

18. Diniz EM, Morita ABPS, Paula MAB. Situação de risco para úlceras por pressão em uma unidade de assistência domiciliar. Rev Estima. 2016;14(2):53-60. Z1806-3144201600020002

19. Sousa Júnior BS, Silva CC, Duarte FHS, Mendonça AEO, Dantas DV. Análise das ações preventivas de úlceras por pressão por meio da escala de Braden. Rev Estima. 2017;15(1):10-8. https:// doi.org/10.5327/Z1806-3144201700010003

20. Ramos DO, Oliveira OS, Santos IV, Carvalho ES, Passos SS, Góis JA. Conhecimento de familiares acerca das úlceras por pressão e de seus direitos à reparação. Rev Baiana Enferm. 2014;28(1):23-30.

21. Almeida R, Giacomolli CMH, Coelho EL, Bittencourt VLL, Callegaro CC, Stumm EMF. High frequency generator in the treatment of injury by pressure in elderly. J Nurs UFPE Online. 2017;11(8):3136-42. https://.doi.org/10.5205/ reuol.11064-98681-4-ED.1108201719

22. Nogueira GA, Assad LG. Avaliação de risco para úlcera por pressão: contribuição para o cuidado de enfermagem na unidade de clínica médica. Rev Enferm UFPE. 2013;7(11):6462-70. https://doi.org/10.5205/reuol.3794-32322-1ED.0711201320

23. Mittag BF, Crozeta K, Roehrs H, Stocco J, Meier MJ. Continuing education about pressure ulcers. J Nurs UFPE Online. 2016;10(8):3020-3027. https://doi.org/10.5205/reuol.9373-82134-1RV1008201629

24. Luz SR, Lopacinski AC, Fraga R, Urban CA. Úlcera por pressão. Geriatr Gerontol. 2010;4(1):36-43. 